\title{
Synthesis of poly (amidoamine) (PAMAM) dendrimer-based chitosan for targeted drug delivery and cell therapy
}

\author{
Leila Sofi Maryo ${ }^{1}$, Nahid Haghnazari ${ }^{*}$, Fatemeh Keshavarzi $^{2 *}$, Hassan Zhaleh ${ }^{3}$, Farzad \\ Seidi $^{4}$
}

1. Department of Biochemistry, Sanandaj Branch, Islamic Azad University, Sanandaj, Iran

2. Department of Biology, Sanandaj Branch, Islamic Azad University, Sanandaj, Iran

3. Substance Abuse Prevention Research Center, Kermanshah University of Medical Sciences, Kermanshah, Iran

4. Department of Chemistry, Sanandaj Branch, Islamic Azad University, Sanandaj, Iran

*Corresponding authors:Tel: +98 9183704918, +9181315122 Fax: +98 8733288677

Address: Department of Biology, Sanandaj Branch, Islamic Azad University, Sanandaj, Iran; Department of Biochemistry, Sanandaj Branch, Islamic Azad University Pasdaran Ave., Sanandaj, Iran

E-mail: n.haghnazari@gmail.com; fkeshavarzi@iausdj.ac.ir

Received; 2018/07/15 revised; 2018/08/16 accepted; 2018/09/18

\section{Abstract}

Introduction: In the current study we designed a sophisticated drug delivery nanoparticle to control the methylprednisolone succinate delivery rate and affect the cancer cell growth in culture condition.

Materials and methods: Magnetic nanoparticles were synthesized through co-precipitation method. $\mathrm{Fe}_{3} \mathrm{O}_{4}$ was first prepared via co-precipitation method and then its surface was functionalized with polyamidoamine (PAMAM) nanodendrimer. PAMAM synthesis trait was detected via FT-IR and SEM methods. Methylprednisolone drug was loaded on PAMAM@ $@ \mathrm{Fe}_{3} \mathrm{O}_{4}$ and its effect against cancer cell lines was studied. In order to slow down drug release rate from nanoparticles, PAMAM@ $\mathrm{Fe}_{3} \mathrm{O}_{4}$ were coated with trimethylchitosan (TMC) after drug loading. Performance of PAMAM@ $@ \mathrm{Fe}_{3} \mathrm{O}_{4} @ \mathrm{TMC}$ nanoparticles loaded with mmethylprednisolone, were evaluated against two cell lines to detect the cytotoxic and apoptotic effects by invert light scanning microscopy, immunoassay, and LDH cytotoxicity Kit.

Results: According to SEM, image size of $\mathrm{Fe}_{3} \mathrm{O}_{4}$ was $4.79-6.37 \mathrm{~nm}$, which is smaller than nanodendrimer (6.30-43.67 nm). FT-IR spectrum for ester bond Methylacrylate @ Ethylendiamin was obtained to be 1720-1730 $\mathrm{cm}^{-1}$. FT-IR Spectrums $600 \mathrm{~cm}^{-1}, 1000 \mathrm{~cm}^{-1}$ belong to $\mathrm{Fe}_{3} \mathrm{O}_{4}$, and $\mathrm{Fe}_{3} \mathrm{O}_{4} @ \mathrm{NH}_{2}$. Also, trimethyl chitosan coated Nanoparticle @ Drug, smearing trimethyl chitosan with Glutaraldehyde, created cross link between TMC monomer at low drug doses in each complete nanoparticle, gave confidence drug side effect, therefore, this nanoparticle could be safe for future cancer therapy.

Conclusion: The results showed that drug delivery via PAMAM@ $\mathrm{Fe}_{3} \mathrm{O}_{4}$ nanoparticle reduces cell viability in vitro condition.

Keywords: PAMAM dendrimer, Fe3O4, Trimethylchitosan, Cytotoxicity, Magnetic, Drug delivery

\section{Introduction}

In recent years numerous researches have

been done on nano carriers such as nano

Copyright (C) 2018 Journal of Basic Research in Medical Science. This is an open access article distributed under the terms of the Creative Commons Attribution 4.0 International License (https://creativecommons.org/licenses/by/4.0/) which permits copy and redistribute the material, in any medium or format, provided the original work is properly cited. 
dendrimers and nano polymers to create adequate drug delivery systems suitable for cancer or infection treatments (1). Nano carriers are more interested in modern medicine treatment. Dendrimer is known because of its unique three molecular structure, and branch like arms built high number of active terminal end groups (2). These terminal end groups help dendrimers to bond to the surface of nanoparticles sake direct transfer to target. $\mathrm{Fe}_{3} \mathrm{O}_{4}$ as a nanoparticle core structure has high stability in acidic/basic conditions. Nowadays scientists have more challenges on target therapy (3). This procedure without any damage to other normal cells has goal preference to old drug using form (4). This newer cancer therapy aims to lower side effects caused by the chemotherapy on patients. Drugs taken orally or intravenously have significant side effects on healthy tissues (5-6). The localization filed of magnetic nanoparticle has a power to make assignable spot methylprednisolone deliverance. Methylprednisolone derived from prednisolone as a glucocorticoid such as an anti- inflammatory drug with anti-cancer effect (7-8). Methylprednisolone side effects are osteoporosis, cataract, glaucoma, infection symptom, redness, swelling, tenderness, fatigue, weakness, dizziness, bone pain, vomiting, nausea, headache, change in vision, slow wound curing, potassium loss, emotion change, high blood pressure, tine and fragile skin. FDA has subscribed methylprednisolone as leukemia and non-Hodgkin lymphoma treatment, that utilize as oral, intravenous or intramuscular dose of methylprednisolone facilitate apoptosis via JAK/STATE pathway in cancer leukemic cells (9).

BCL2 protein has encoded by BCL2 gene.
This gene translated between numbers 14 , 16 chromosomes. BCL2 anti apoptotic protein located on outer mitochondrial membrane, BAX and BAK are pro apoptotic proteins normally placed in outer mitochondrial membrane (10). BCL2 gene damage develop various cancers like, leukemia, melanoma, breast, prostate and lung cancer. Bax expression regulated is by P53 protein (11). This inhibits the interaction between $\mathrm{Bax}$ and $\mathrm{Bcl}-\mathrm{xl}$ proteins. In cancer therapy $\mathrm{Bcl}-2$ protein have been reported to has a chemo resistant effect. Bcl -2 family is an antiapoptotic protein so decreasing the expression levels of $\mathrm{Bcl}-2$ or Bcl-xl by gene therapy can help the cancer treatment process(12).

Bax is a proapoptotic protein. Bax homodimerization causes apoptosis, while hetero dimerization between Bax (an apoptotic protein ) and Bcl-2 or Bcl-xl (an anti- apoptotic protein) inhibit apoptosis (13). Therefore, methylprednisolone lead to apoptosis via inhibition hetero dimerization between Bax and BCL proteins or inhibit homodimerization $\mathrm{Bcl}-2$ or Bcl-xl. Methylprednisolone succinate drug has been loaded on dendrimer in order to test its performance on cancer cells generation. Then, $\mathrm{Fe}_{3} \mathrm{O}_{4} @ \mathrm{PAMAM} /$ drug was coated with TMCS and assay drug releasing rate in bicarbonate buffer at $7.30 \mathrm{pH}$ normal human boold $\mathrm{pH}$. In this study, a drug delivery system was designed by an intelligent nanoparticle to control the methylprednisolone succinate delivery rate and its effects on cancer cell culture.

\section{Materials and methods}

\section{Materials}

Nanoparticle and quaternary chitosan synthesis material: $\mathrm{FeCl}_{3} \cdot 6 \mathrm{H}_{2} \mathrm{O}$ (Sigma), $\mathrm{FeCl}_{2} .4 \mathrm{H}_{2} \mathrm{O}$ (Sigma), ammonia solution (25\%), methyl acrylate (Sigma, ), chitosan, methyl iodide, ethylenediamine, triethoxysiliylpropilamine, N-methyl pyrolidone, methyl prednisolone, sodium iodide, acetic acid, glutaraldehyde all 
were purchased from Sigma Aldrich.

Cell culture material: RPMI1640 (Gibco, USA), FBS (Gibco, USA), NEAA (Gibco, USA), L-Glutamine (Sigma, USA), Penicillin (Sigms, USA), Streptomycin (Sigma, USA), LDH Cytotoxicity kit (Roche, Germany), Hoechst33342 (Sigma, USA), Propodium Iodide (Sigma, USA).

Characterization: SEM images were achieved by MIRAS TESCAN - SEM HV: $30.0 \mathrm{KV}$-WD: 4/25 mm. FTIR analysis were obtained by utilization KBR discs in $400-4000 \mathrm{~cm}^{-1}$ area with $\mathrm{ABB}$ Boomed MB - 100 FT- IR spectrophotometer. Release of loaded drug was measured with UV spectrometer at $284 \mathrm{~nm}$ in $40 \mathrm{~min}$ interval times for 24 hours. MCF -7 and Jeg- 3 apoptosis and necrosis acquired by cell attribute an invert- florescence microscopic (Olympus IX-71, Japan). Cytotoxicity was dealt by LDH cytotoxicity kit. Eliza reader (EL800: USA) used to LDH activity colorimetric. All data analysis was done via SPSS softwar.

Synthesis of magnetic $\mathrm{NanoFe}_{3} \mathrm{O}_{4}$ : Magnetic nanoparticles were synthesized through the co-precipitation method. Briefly, $7.6 \mathrm{~g} \quad \mathrm{FeCl}_{3} .6 \mathrm{H}_{2} \mathrm{O}, 3.1736 \mathrm{~g}$ $\mathrm{FeCl}_{2} .4 \mathrm{H}_{2} \mathrm{O}$ were dissolved in $320 \mathrm{ml}$ deionized water under $\mathrm{N}_{2}$ atmosphere at 80 ${ }^{\circ} \mathrm{C}$ using magnetic string for one hour. Then, $\mathrm{pH}$ of the reaction mixture was adjusted on 12 by addition $40 \mathrm{~mL} \mathrm{NH}_{3}$. Dark black nanoparticles instantly formed after addition of ammonia. Stirring was continuing for another one hour and room temperature under nitrogen atmosphere. Finally, magnetic $\mathrm{Fe}_{3} \mathrm{O}_{4}$ nanoparticles were separated using neodymium magnet. The nanoparticles were washed two more times with deoxygenated distilled water, two time with ethanol and one time with diethyl ether. Finally, nanoparticles were separated by neodymium magnet and dried in under vacuum at room temperature.

Surface modification of $\mathrm{Fe}_{3} \mathrm{O}_{4}$ by the amine group (Fe3O4@NH2): Six ml triethoxylsilyl propylamine was mixed with to $3 \mathrm{~g} \mathrm{Fe}_{3} \mathrm{O}_{4}$ in $40 \mathrm{ml}$ toluene and stirred using magnetic stirrer for 3 days under $\mathrm{N}_{2}$ atmosphere at $60{ }^{\circ} \mathrm{C}$. The produced $\mathrm{Fe}_{3} \mathrm{O}_{4} @ \mathrm{NH}_{2}$ nanoparticles were separated by neodymium magnet and washed two times with ethanol and then dried in desiccator under vacuum.

Incorporation of PAMAM dendrimer on the surface of $\mathrm{Fe}_{3} \mathrm{O}_{4} @ \mathrm{NH}_{2}$ nanoparticles: Sequential reaction of $\mathrm{Fe}_{3} \mathrm{O}_{4} @ \mathrm{NH}_{2}$ with methyl acrylate (MA) (Michael reaction) and then with ethylene diamine (EA) (amidation) was performed to created PAMAM on the surface of magnetic nanoparticles. Briefly, $10 \mathrm{~mL}$ methyl acrylate was mixed with $3 \mathrm{~g}$ $\mathrm{Fe}_{3} \mathrm{O}_{4} @ \mathrm{NH}_{2}$ in $20 \mathrm{~mL}$ of methanol and the mixture was stirred for 3 days at room temperature to complete the Michael reaction between primary amino groups of the $\mathrm{Fe}_{3} \mathrm{O}_{4} @ \mathrm{NH}_{2}$ with methyl acrylate. The obtained $\mathrm{Fe}_{3} \mathrm{O}_{4} @ \mathrm{MA} 1$ product was separated by neodymium magnet and washed two times with methanol and separated again with neodymium magnet. Afterward, $\mathrm{Fe}_{3} \mathrm{O}_{4} @ \mathrm{MA} 1$ was mixed with $7.5 \mathrm{~mL}$ EA and $20 \mathrm{~mL}$ methanol and the mixture was stirred was stirred for 3 days at room temperature to complete the amidation reaction between ester groups of the $\mathrm{Fe}_{3} \mathrm{O}_{4} @ \mathrm{MA} 1$ with EA and afford $\mathrm{Fe}_{3} \mathrm{O}_{4} @ \mathrm{EA} 1$. The sequential reaction with $\mathrm{MA}$ and EA was repeated two more time to produce $\mathrm{Fe}_{3} \mathrm{O}_{4} @ \mathrm{EA} 3$.

Incorporation of negative charges on the surface of $\mathrm{Fe}_{3} \mathrm{O}_{4} @$ PAMAM nanoparticles: $\quad \mathrm{Fe}_{3} \mathrm{O}_{4} @$ PAMAM nanoparticles $(2 \mathrm{~g})$ were dispersed in 30 $\mathrm{mL}$ ethanol. Afterward, $12 \mathrm{~g}$ chloroacetic acid and $5 \mathrm{~g}$ sodium hydroxide were added to the mixture and the mixture was stirred for a week at room temperature. Finally, the product was separated using neodymium magnet and washed several times with ethanol. Finally, the $\mathrm{Fe}_{3} \mathrm{O}_{4} @ \mathrm{PAMAM} @ \mathrm{COONa}$ product was separated and dried at room temperature under vacuum.

Synthesis of trimethyl chitosan (TMC): $2 \mathrm{~g}$ chitosan and $4.8 \mathrm{~g}$ sodium iodide were mixed in $80 \mathrm{~mL} \mathrm{~N}$-methyl pyrrolidone. 
Then, $11 \mathrm{~mL}$ of $\mathrm{NaOH}$ aqueous solution $(0.15 \mathrm{M})$ and $11 \mathrm{~mL}$ methyl iodide were added to the mixture. The mixture was stirred at $50{ }^{\circ} \mathrm{C}$ for $24 \mathrm{~h}$ to obtain a brown solution. The solution was poured into ethanol to afford the quaternary ammonium salt of chitosan as a yellow precipitate. Product was separated and washed several time with ethanol and finally with diethyl ether and then dried at room temperature.

Loading complex of methylprednisolone (MP) in the magnetic nanoparticles and subsequent coating with TMC: $0.4 \mathrm{~g}$ of $\mathrm{Fe}_{3} \mathrm{O}_{4} @ \mathrm{PAMAM} @ \mathrm{COONa}$ nanoparticles were dispersed in $2 \mathrm{~mL}$ of distilled water, then, $0.3 \mathrm{~g}$ MP was added to the mixture. The mixture was stirred for 24 hours, then $0.4 \mathrm{~g}$ TMC was added to the mixture to coat the nanoparticles. After $2 \mathrm{~h}, 320 \mu \mathrm{L}$ glutaraldehyde was added to the mixture to create some covalent crosslinking on the TMC structure to fix it as a shell on the surface of nanoparticles. Finally, $\mathrm{Fe}_{3} \mathrm{O}_{4} @ \mathrm{PAM}$ AM@COONa@TMC

nanoparticles loaded with MP were separated neodymium magnet and washed one time with distilled water and then dried at room temperature and used of further experiments.

Release of MP from magnetic nanoparticles: $0.4 \mathrm{~g}$ of MP-loaded nanoparticles were dispersed in $10 \mathrm{~mL}$ bicarbonate buffer $(\mathrm{pH} \sim 7.3, \mathrm{C} \sim 0.05 \mathrm{M})$ and in different interval times $500 \mu \mathrm{L}$ of the clear solution was taken and replaced by $500 \mu \mathrm{L}$ of fresh buffer to keep the total volume of the release medium constant. The UV adsorption of each taken sample was recorded via UV spectrometer at 284 nm.

Cell Culture: JEG-3 and MCF-7 cells were grown in RPMI1640 culture media (Gibco,USA), supplemented with $10 \%$ fetal bovine serum (FBS, Gibco,USA), $1 \%$ amino acid (NEAA, Sigma), 2mM Lglutamine (Sigma), 100IU/ml penicillin (Sigma), and $100 \mu \mathrm{g} / \mathrm{ml}$ streptomycin (Sigma) in T-25 $\mathrm{cm}^{2}$ tissue culture flasks. The cultures were incubated in $5 \% \mathrm{CO}_{2}$ at $37^{\circ} \mathrm{C}$.

Cell treatment: Overnight after plating the cells, cells were washed with PBS (Phosphate-buffered saline), $\mathrm{pH}$ 7.4. There were three groups: Group I: incubated with drug, Group II: incubated with nanoparticles, and Group III: incubated with nanopartical complex. There were eight treatments in each group including; control: $0.0 \mu \mathrm{g}$, treatment $1: 2.5 \mu \mathrm{g}$, treatment 2: $5 \mu \mathrm{g}$, treatment 3: $10 \mu \mathrm{g}$, treatment 4: $20 \mu \mathrm{g}$, treatment 5: $40 \mu \mathrm{g}$, treatment 6: $80 \mu \mathrm{g}$, and treatment 7: 160 $\mu \mathrm{g}$. Then, the cells were placed in the incubator with $5 \% \mathrm{CO}_{2}$ at $37^{\circ} \mathrm{C}$. The cells were cultured in RPMI1640 culture medium.

Cell viability measurement: Cell viability was quantified by measuring the release of lactate dehydrogenase (LDH) from damaged or destroyed cells in the medium. Cytotoxicity was measured with LDH cytoxicity detection Kit (Roche, Germany) which detected LDH release from dead cells. The increase of LDH activity in each treatment showed that the treatment solution had cytotoxicity effects and caused further dead cells. Cells were plated in 24 well culture plates with $10^{4}$ cells $/ \mathrm{mL}$ densities for overnight. Then, cells were cultured by the different treatment media for $24 \mathrm{~h}$. The percentage of cytotoxicity was measured by the protocol from company (Roche, Germany); the colorimetric of $\mathrm{LDH}$ activity measured by the calculated absorbance of samples at 490 or $492 \mathrm{~nm}$ using an ELISA Reader (EL800; USA). The reference wavelength should be more than $600 \mathrm{~nm}$. All experiments were replicated independently for at least 3 times. Within each experiment, we replicated each condition 4 times.

Quantification of cell death incidence: Hoechst/PI nuclear staining was carried out. Briefly, cells were plated in 24 well culture plates with $10^{4}$ cells $/ \mathrm{mL}$ density for overnight. Then, cell $\mathrm{s}$ were cultured in different treatment media for 24 hours. Then, cells were incubated for $15 \mathrm{~min}$ at 
$37^{\circ} \mathrm{C}$ with Hoechst 33342 dye $(10 \mu \mathrm{g} / \mathrm{ml}$ in PBS), washed twice in PBS PI (50 $\mu \mathrm{g} / \mathrm{ml}$ in PBS) before characterization of cells using an inverted-florescence microscope (Olympus IX-71, Japan). The apoptotic index was calculated by the ratio of apoptotic cells over the total cell count (at least 500 cells) in (). All experiments were independently replicated for at least 3 times. Within each experiment, we replicated each condition 4 times.

\section{Results}

According to SEM, the image size of $\mathrm{Fe} 304$ was $5.61-17.46 \mathrm{~nm}$, which was smaller than nanodendrimer (6.30-43.67 $\mathrm{nm})$. FT-IR spectrum for ester bond of Methylacrylate @ Ethylendiamin was obtained to be $1720-1730 \mathrm{~cm}^{-1}$. FT- IR spectrums $600 \mathrm{~cm}^{-1}, 1000 \mathrm{~cm}^{-1}$ belong to $\mathrm{Fe}_{3} \mathrm{O}_{4}$, and $\mathrm{Fe}_{3} \mathrm{O}_{4} @ \mathrm{NH}_{2}$, respectively.

Cell viability and death: Cell group treatments (3 groups) were as follow: Group I: incubated with methylprednisolone, Group II: incubated with PAMAM nano-particles, Group III: incubated with nanoparticle complex. There were eight treatments in each group, including control: $0.0 \mu \mathrm{g}$, treatment $1: 2.5$ $\mu \mathrm{g}$, treatment 2: $5 \mu \mathrm{g}$, treatment 3: $10 \mu \mathrm{g}$, treatment 4: $20 \mu \mathrm{g}$, treatment 5: $40 \mu \mathrm{g}$, treatment 6: $80 \mu \mathrm{g}$, and treatment 7: 160 $\mu \mathrm{g}$. Methylprednisolone and nanoparticle complex induced cells death in JEG-3 and MCF-7 cell lines. We used double staining of PI and Hoechst to detect cell death and cell viability in the groups of cultured cells. At first, cells were exposed to different treatment media, then, cell viability was measured by LDH assay after a 24h-exposure. In Group I, the percentage of cell viability for treatments 4-7 decreased compared with control cells $(\mathrm{P}<0.05)$. In Group II, the exposure of cells to different concentrations of nanoparticle decreased the cell viability in treatments 4-7 compared with control cells $(\mathrm{P}<0.05)$. In addition, the percentage of cell viability in treatment 7 decreased compared with treatments $1-4(\mathrm{P}<0.05)$. In
Group III, the exposure of cells to different concentrations of nanoparticle complex decreased the cell viability in treatments 27 compared with control cells $(\mathrm{P}<0.05)$. The percentage of cell viability in treatment 7 (compared with treatment 6), 6 (with 5), 5 (with 4) and 4 (with 3) decreased $(\mathrm{P}<0.05)$. All data represented as mean $\pm \mathrm{SD} \mathrm{P}<0.05)$.

\section{Discussion}

PAMAM nanoparticles features size, surface, charge is necessary for creating good target attachment. Drug delivery in different parts of human body, requires different nanoparticle design. Recently, nanoparticle drug delivery toward fibroblast culture was done by AJAY KUMAR and his team. In that study, magnetic $\mathrm{Fe} 3 \mathrm{o} 4$ core was covered by poly ethylene glycol (PEG). They recognized fibroblast nanoparticle absorption depend on surface spreading, hydrophobicity, hydrophilicity, determined cell result contact and sufficient cell uptake. Great cell membrane penetration to nanoparticle coated with PEG reduce cell toxicity, these phenomena developed by high PEG solubility (14). The PEG coated nanoparticle had no destructive effects on cell culture at $0-1000 \mu \mathrm{g} / \mathrm{ml}$, but cytotoxicity was increased at higher concentration (15). Intracellular endocytosis drug delivery control of MCM-41 Mesoporous silica nanoparticle (MSN) human cancer against different MCM-41 concentration was detected by flow cytometry green fluorescent. MSN negative charge exhaust from endosomes after 6 hours but positive MSN charge remain longer time in endosomes. MCM41 cell uptake and endosome confirmation is impressed by diverse surface functionalization, which is important in the design of nanoparticle for cell delivery (16). Studying about cancer target therapy PAMAM dendrimer polymer $<5 \mathrm{~nm}$ conjugated with Folic acid - methotrexate anti-cancer drug, has been used in human epithelial mice model and human KB 
tumor.Drug@nanoparticle internalization in tumor cells access anti-tumor functionalization and abate cytotoxicity compared with free drug (17). Studies pointed that the polymer $(\mathrm{D}, \mathrm{L}$ lactide-coglycoside) (PLGA), nanoparticle size specification biodegradable, biocompressable has a good appointment in the cellular entrance with $100 \mathrm{~nm}$ size 2.5 fold rather than $1 \mu \mathrm{m}$ and 6 fold better cell entree compare to $10 \mu \mathrm{m}$ (18). Nanoparticle can pass blood brain barrier to access brain cancer tumor. Nanoparticle has moderate cell arrival in submicron size but not in microparticle bulk. Nanoparticle can penetrate sub-mucosa layer while microparticle centralized epithelial layer. Recently recognized dendrimers synthesized by covalent band has no critical micellar concentration to make it unstable. So deliverance time be prolixed even at less concentration cooperation with micellar concentration. Covalent ligand bond is helpful for target therapy lead delivery being stable for longer time (19). Cationic surface Silica nanoparticle built in three branch Si 10E, Si 100E, Si $26 \mathrm{H}$ conduct DNA plasmid in a sufficient rate and make low cell toxicity in vitro. this nanoparticle@DNA named nanoplex 10$100 \mathrm{~nm}$ zeta potential +7 to $+31 \mathrm{mv}$ at $\mathrm{pH}$ 7.4 (18). Intracellular uptake of PAMAM Mesoporous silica (MSN) nanoparticle via endocytosis develop MSN centralized in mitochondria and golgi body, confirmed cell uptake with clathrin, caveolin, receptor, or without clathrin, caveolin, to cytoplasm is done (20). Last decade indicates the magnetic polyamidoamine nanoparticle, PAMAM Dendrimer with 8 nm size success gene therapy in cancer cell (21). Nanoparticle drug delivery is benefit for curing alzheimer, central nervous system disease (CNS), brain cancer, whereas brain is not within reach per medicine. Blood brain barrier allow only 400-600 Dalton weight to cross from it, increase half live, stability, solubility, low toxicity and power for cross blood brain barrier establish nanoparticle as a proper solution in brain curing disease(22). Drug with covalent bond to dendrimers show low drug extrication in contrast to noncovalent bond (23). Oral doses of nanoparticle in different size lead to colitis and other complaint, nanoparticle sediment by Helicobacter pylori in stomach should be envisage (24). The quantitative system for multivalent reaction nanoparticle and folate banding protein with different folate dose was designed. Observed interaction depend on dendrimers ability to bind target not to maximum scale drug load (25). Nanoparticle 200nm size have toxic effect on endothelial nerve cell and hemolysis but not all nanoparticles type. Anionic nanoparticle with low concentration assigned no toxic effect against blood brain barer or anticoagulant effect (26). In 2004 Khin yin win and assistant accent nanoparticle surface schema, surface coating, and size indicate its cellular uptake, showing this cell up take is saturate (24). Another study ensign cationic dendrimer has anti-coagulant, toxic effect than anionic type by elevated nitrogen urea, blood alanine transaminase sequence cause kidney, and liver toxicity. But anionic nanoparticle suggests no hemolytic, cytokine release (22-26).

\section{Conclusion}

PAMAM@Fe3O4 elevates drug delivery rate at low doses and has confidence drug side effect therefore it could be safe for future cancer therapy. Nanoparticle complex induced cell death or decreased viability in MCF-7 and JEG-3 cancer cell lines. The results showed that nanoparticle complex has enhanced cell death and reduced cell viability in experiment.

\section{Acknowledgement}

The authors would like to also extend their sincere appreciation to the Department of Biochemistry and Nutrition, School of Medicine, Kurdistan University of Medical Sciences, Sanandaj, Iran. 


\section{Declaration of interest}

There is no conflict of interest.

\section{Author contribution}

Nahid Haghnazari, Fatemeh keshavarzi, Farzad Seidi and Hassan Zhaleh designed

\section{References}

1. Prieto MJ, del Rio Zabala NE, Marotta $\mathrm{CH}$, Carreño Gutierrez $\mathrm{H}$, Arévalo Arévalo R, Chiaramoni NS, et al. Optimization and in vivo toxicity evaluation of G4.5 PAMAM dendrimer-risperidone complexes. PLoS One. 2014;9(2):e90393. doi: 10.1371/journal.pone.0090393.

2. Brunetti FG, Herrero MA, de Mun oz J, D1'az-Ortiz A, Alfonsi J, Meneghetti $M$, et al. Microwaveinduced multiple functionalization of carbon nanotubes. J Am Chem Soc. 2008; 130(25):8094-100. doi: 10.1016/j.carbon.2012.02.050.

3. Shi X, Wang SH, Shen M, Antwerp $\mathrm{ME}$, Chen $\mathrm{X}$, $\mathrm{Li} \mathrm{C}$, et al. Multifunctional dendrimer-modified multiwalled carbon nanotubes: synthesis, characterization, and in vitro cancer cell targeting and imaging. Biomacromolecules. 2009;10(7):1744-50. doi: 10.1021/bm9001624.

4. Tomalia DA, Baker H, Dewald J, Hall M, Kallos G, Martin S, et al. A new class of polymers: starburstdendritic macromolecules. Polym J. 1985; 17(1):117-32. doi: 10.1186/1556-276X-9-247.

5. Cakara D, Kleimann J, Borkovec M. Microscopic protonation equilibria of poly(amidoamine) dendrimers from macroscopic titrations. Macromolecules. 2003; 36(11): 42017. doi: $10.1021 / \mathrm{ma} 0300241$.

6. Pagona G, Karousis N, Tagmatarchis N. Aryl diazonium functionalization of carbon nanohorns. Carbon and conducted the study. Fatemeh keshavarzi, Farzad Seidi and Hassan Zhaleh wrote the paper; Leila Sofi Maryo conceived the experiments, prepared the tables and figures. All authors gave final approval for the manuscript to be submitted for publication.
2008;46(4):604-10.

doi: $10.1021 / \mathrm{cm} 0604864$.

7. Lacerda L, Ali-Boucetta H, Herrero MA, Pastorin G, Bianco A, Prato M, et al. Tissue histology and physiology following intravenous administration of different types of functionalized multiwalled carbon nanotubes. Nanomedicine. 2008;3:149-61. doi: 10.2217/17435889.3.2.149.

8. Campidelli S, Sooambar C, Lozano Diz E, Ehli C, Guldi DM, Prato M. Dendrimer-functionalized single-wall carbon nanotubes: synthesis, characterization, and photoinduced electron transfer. J Am Chem Soc. 2006;128(38):12544-52. doi: 10.1021/ja063697i.

9. Rubio N, Herrero MA, Meneghetti M, Di'az-Ortiz A, Schiavon M, Prato M, et al. Efficient functionalization of carbon nanohorns via microwave irradiation. J Mater Chem. 2009;19:4407-13. doi: 10.1039/B900776H.

10. Brunetti FG, Herrero MA, de Mun oz J, Di'az-Ortiz A, Alfonsi J, Meneghetti $M$, et al. Microwaveinduced multiple functionalization of carbon nanotubes. J Am Chem Soc 2008;130(25):8094-100. doi: $10.1021 / j a 053003 q$.

11. Vashist SK, Zheng D, Pastorin G, AlRubeaan K, Luong JHT, Sheu FS. Delivery of drugs and biomolecules using carbon nanotubes. Carbon. 2011;49(13):4077-97. doi: 10.1016/j.carbon.2011.05.049.

12. Lacerda L, Bianco A, Prato M, Kostarelos K. Carbon nanotube cell 
translocation and delivery of nucleic acids in vitro and in vivo. $\mathrm{J}$ Mater Chem. 2008;18(1):17-22. DOI: 10.1039/B711554G.

13. Lacerda L, Soundararajan A, Singh R, Pastorin G, Al-Jamal K, Turton J, et al. Dynamic imaging of functionalized multiwalled carbon nanotube systemic circulation and urinary excretion. Adv Mater. 2008;20(2):225-30. doi: 10.1002/adma.200702334

14. Isobe $\mathrm{H}$, Tanaka $\mathrm{T}$, Maeda $\mathrm{R}$, Noiri E, Solin N, Yudasaka M, et al. Preparation, purification, characterization, and cytotoxicity assessment of water-soluble, transition-metalfree carbon nanotube aggregates. Angew Chem Int Ed. 2006;45(40):6676-80. doi: 10.1002/ange.200601718.

15. Price BK, Tour JM. Functionalization of single-walled carbon nanotubes "'On Water". J Am Chem Soc. 2006;128(39):12899-904. doi: $10.1021 / \mathrm{ja} 063609 \mathrm{u}$.

16. Niu Y, Sun L, Crooks RM. Determination of the intrinsic proton binding constants for poly(amidoamine) dendrimers via potentiometric $\mathrm{pH}$ titration. Macromolecules. 2003;36(15):572531. doi: $10.1021 / \mathrm{ma} 034276 \mathrm{~d}$.

17. Gomez MV, Guerra J, Velders AH, Crooks RM. NMR characterization of fourth-generation

PAMAM dendrimers in the presence and absence of palladium dendrimerencapsulated nanoparticles. J Am Chem Soc. 2009;131(1):341-50. doi: 10.1021/ja807488d.

18. Zhang YR, Wang SQ, Shen SL, Zhao BX (2013b) A novel water treatment magnetic nanomaterial for removal of anionic and cationic dyes under severe condition. Chem Eng J. 213:258-64. doi: 10.1016/j.cej.2013.07.009.

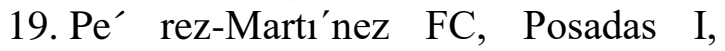
Guerra J, Cen a V. Barriers to non- viral vectors-mediated gene delivery in the nervous system. Pharm Res. 2011;28(8):1843-58. doi 10.3233/JAD-2012-120661.

20. Park JH, Dao TD, Lee HI, Jeong HM, Kim BK. Properties of graphene/shape memory thermoplastic polyurethane composites actuating by various methods. Materials. 2014;7: 1520-38. doi: 10.3390/ma7031520.

21. Pecora R. Dynamic light scattering measurement of nanometer particles in liquids. J Nanopart Res. 2000;2(2):123-31. doi: 10.1023/A:1010067107182.

22. Rubio N, Herrero MA, de la Hoz A, Meneghetti M, Prato M, Va'zquez E. Versatile microwave-induced reactions for the multiple functionalization of carbon nanotubes. Org Biomol Chem. 2010; 8:1936-42. doi: $10.1039 / \mathrm{b} 925227 \mathrm{~d}$.

23. Scott RWJ, Wilson OM, Crooks RM. Synthesis, characterization and applications of dendrimer encapsulated nanoparticles. J Phys Chem B. 2005; 109:692-704. doi: 10.1021/jp0469665.

24. Win KY, Feng SS. Effect of partice size and surface on cellular uptake of polymeric nanoparticles for oral delivery of anticancer drugs. Biomaterial. 2005;26(15): 2713-2722.

25. Posadas I, Guerra J, Ceñ a V. Nonviral vectors for the delivery of siRNA to the central nervous system. Nano medicine. 2010;5(8):1219-36. doi: 10.2217/nnm.10.105.

26. Podesta JE, Al-Jamal KT, Herrero MA, Tian B, Ali-Boucetta H, Hegde $\mathrm{V}$, et al. Antitumor activity and prolonged survival by carbonnanotube-mediated therapeutic siRNA silencing in a human lung xenograft model. Small. 2009;5(10):1176-85. doi: 10.1002/smll.200801572. 